\title{
Tuberculous osteomyelitis diagnosed following an incidental finding on bone scintigraphy
}

\author{
Mel Figtree, ${ }^{1}$ Andrew Wines, ${ }^{2}$ lan Reid, ${ }^{3}$ Janice Brewer, ${ }^{4}$ Bernard Hudson ${ }^{1}$ \\ 1 Department of Microbiology and Infectious Diseases, Royal North Shore Hospital, Sydney, Australia; \\ 2Department of Orthopaedics and Trauma Surgery, Royal North Shore Hospital, Sydney, Australia; \\ ${ }^{3}$ Sydney Diabetes High Risk Foot Service, Royal North Shore Hospital, Sydney, Australia; \\ 4Department of Pathology, PaLMS, Royal North Shore Hospital, Sydney, Australia
}

Correspondence to Mel Figtree, melfigtree@yahoo.com.au

\section{DESCRIPTION}

A 47-year-old Sri Lankan man was diagnosed with diabetic neuropathic ulceration of the left hallux. Technetium-99m scintigraphy showed increased uptake corresponding to the ulcer. However an incidental finding of increased uptake was also noted in the right distal tibia (figure 1). The patient had no localising symptoms on the right. His medical history was significant for type 2 diabetes requiring insulin and vasculitis (managed with prednisone $8 \mathrm{mg}$ daily and mycophenolate $250 \mathrm{mg}$ twice daily). The patient immigrated to Australia 1 year prior to presentation. The right distal tibia was non-tender with minor soft tissue swelling and erythema. T1-weighted post-Gadolinium contrast MRI of the right ankle showed a hyperintense collection in the medial malleolus involving the tendon sheath of tibialis posterior and subcutaneous tissues (figure 2). Biopsy showed granuloma with central necrosis and multinucleated giant cells (figure 3). Ziehl-Neelsen stain and PCR for Mycobacterium tuberculosis were negative from the direct sample. A fully sensitive Mycobacterium was

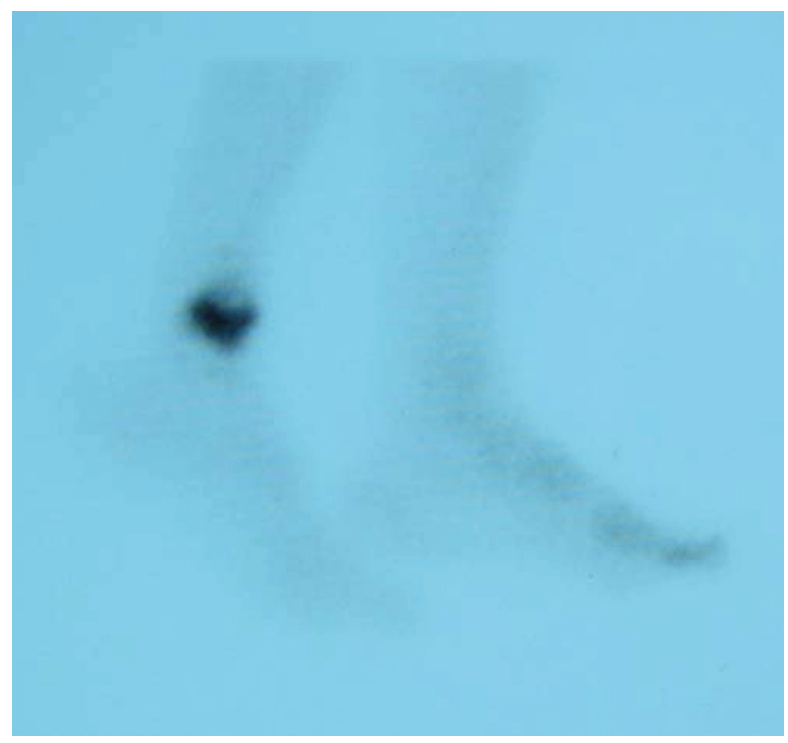

Figure 1 Technetium-99m bone scintigraphy showing incidental increased uptake in the right distal tibia.

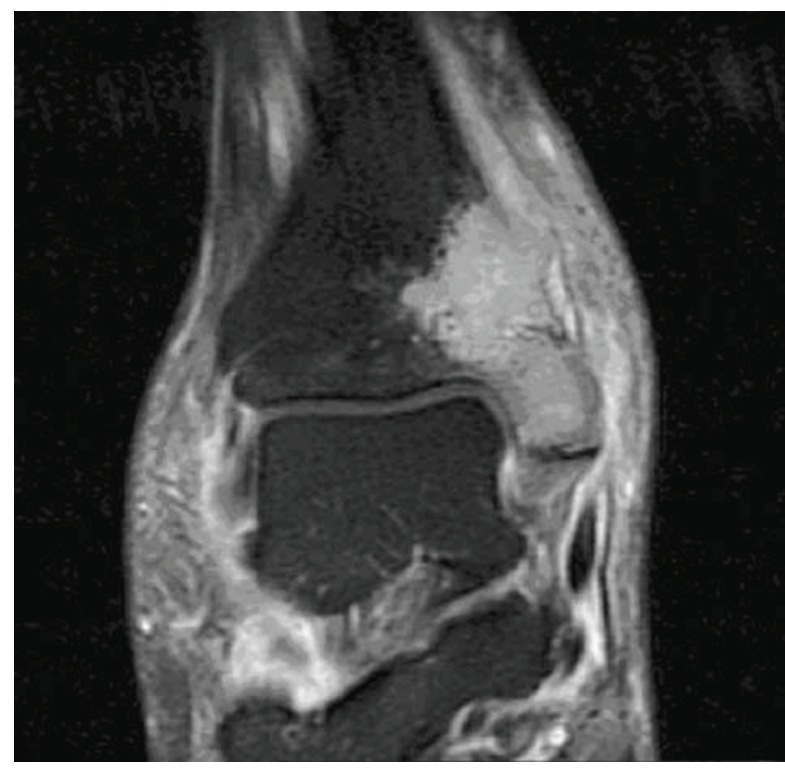

Figure 2 T1-weighted post-Gadolinium contrast MRI of the right ankle showing a hyperintense collection in the medial malleolus with tendon and subcutaneous tissue involvement.

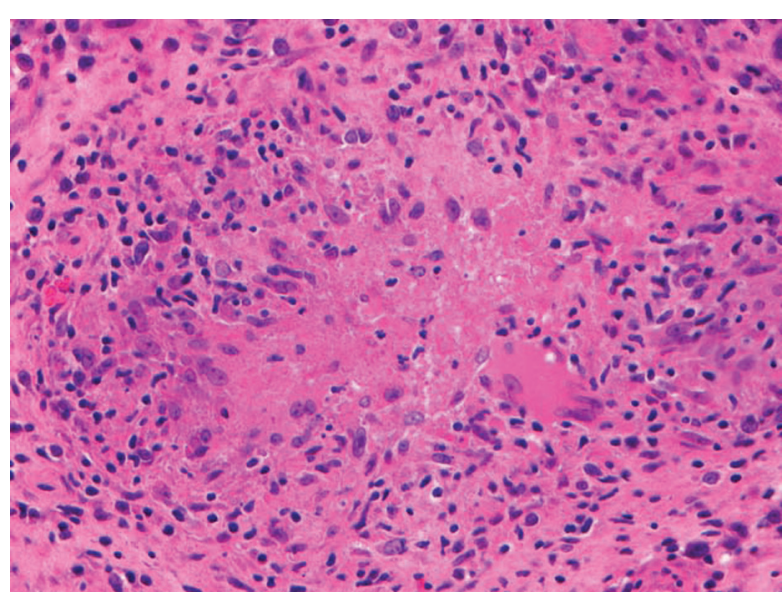

Figure 3 Bone biopsy showing granulomas with central necrosis and multinucleated giant cells. 


\section{BMJ Case Reports}

grown from culture at 2 weeks. This was identified as $M$ tuberculosis by PCR. Chest x-ray was consistent with prior exposure to tuberculosis. Mycophenolate was ceased, prednisolone weaned and the patient was commenced on antituberculosis therapy.

The findings of osseous tuberculosis on bone scintigraphy are not pathognomonic or well defined. False negatives can occur in the setting of caseation. A bone scintigraphy abnormality in a patient from a tuberculous endemic country warrants thorough investigation for the possibility of tuberculosis. Obtaining bone biopsy for culture and sensitivity is crucial to guide therapy.

Competing interests None.

Patient consent Obtained.

This pdf has been created automatically from the final edited text and images.

Copyright 2011 BMJ Publishing Group. All rights reserved. For permission to reuse any of this content visit http://group.bmj.com/group/rights-licensing/permissions.

BMJ Case Report Fellows may re-use this article for personal use and teaching without any further permission.

Please cite this article as follows (you will need to access the article online to obtain the date of publication).

Figtree M, Wines A, Reid I, Brewer J, Hudson B. Tuberculous osteomyelitis diagnosed following an incidental finding on bone scintigraphy. BMJ Case Reports 2011;10.1136/bcr.01.2010.2687, date of publication

Become a Fellow of BMJ Case Reports today and you can:

- Submit as many cases as you like

- Enjoy fast sympathetic peer review and rapid publication of accepted articles

- Access all the published articles

- Re-use any of the published material for personal use and teaching without further permission

For information on Institutional Fellowships contact consortiasales@bmjgroup.com

Visit casereports.bmj.com for more articles like this and to become a Fellow 